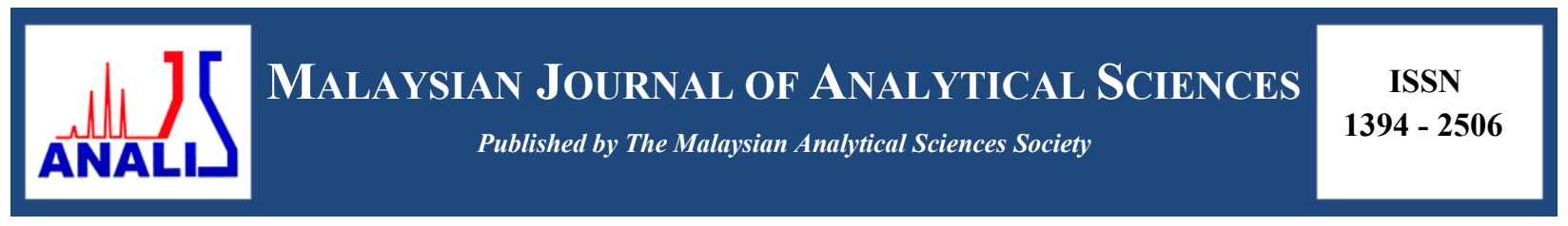

\title{
DETERMINATION OF PHYSICAL CROSSLLINK BETWEEN CARRAGEENAN AND GLYOXYLIC ACID USING DENSITY FUNCTIONAL THEORY CALCULATIONS
}

\author{
(Penentuan Ikatan Sambung Silang Fizikal Antara Karagenan dan Asid Glioksilik Menggunakan \\ Pengiraan Teori Fungsi Ketumpatan)
}

Siti Hana Abu Bakar and Fatmawati Adam*

Faculty of Chemical Engineering \& Natural Resources, Universiti Malaysia Pahang, 26300 Gambang, Pahang, Malaysia

*Corresponding author: fatmawati@ump.edu.my

Received: 28 November 2016; Accepted: 5 February 2017

\begin{abstract}
Film of carrageenan and glyoxylic acid has been produced with an aim for hard capsule application through manipulation of physical crosslink. In this paper, the computational calculation has been used through utilization of density functional theory to predict the possible location of the physical crosslink in the conjugate complex between carrageenan and glyoxylic acid (film of carrageenan and glyoxylic acid). The calculations for pure kappa carrageenan (k-carrageenan), glyoxylic acid and conjugate complex were carried out using Gaussian $09 \mathrm{~W}$; and analysis of molecular electrostatic potential (MESP) was carried out using Gaussview 5. The molecular electrostatic surface potential (MESP) for optimized structure for k-carrageenan and glyoxylic acid have been generated with the red region represents the most negative electrostatic potential which can be found around oxygen and sulphur atoms for the carrageenan molecule. While the blue region that represents the most positive electrostatic potential which can be found around the hydrogen atom far from the double bond oxygen atoms in glyoxylic acid. Therefore, both of this regions may interact and form physical crosslink via hydrogen bond interaction.
\end{abstract}

Keywords: computational analysis, hard capsule, Gaussian 09W, molecular electrostatic potential, hydrogen bond

Filem karagenan dan asid glioksilik telah dihasilkan untuk aplikasi kapsul keras melalui manipulasi kaedah ikatan sambung silang fizikal. Di dalam kertas penyelidikan ini, pengiraan komputer menggunakan teori fungsi ketumpatan telah digunakan untuk mengenalpasti lokasi ikatan sambung silang fizikal yang terbentuk di dalam kompleks kappa-karagenan dan asid glioksilik. Penggiraan teori telah dilakukan untuk struktur kappa-karagenan, asid glioksilik dan kompleks kappa-karagenan-asid glioksilik menggunakan perisian Gassian 09W; dan analisis keupayaan elektrostatik molekul (MESP) dilakukan menggunakan perisian Gaussview 5. Ikatan sambung silang dapat ditentukan berdasarkan gambar-gambar MESP yang dihasilkan. Ikatan sambung silang tersebut dapat dilihat melalui interaksi antara keupayaan elektrostatik negatif (atom oksigen, dan sulfur di dalam karagenan) dan keupayaan elektrostatik positif (atom hydrogen di dalam asid glioksilik). Maka, kedua - dua bahagian ini mempunyai interaksi dan membentuk sambung silang fizikal melalui interaksi ikatan hidrogen

Kata kunci: analisis pengiraan, kapsul keras, Gaussian 09W, keupayaan elektrostatik molekul, ikatan hidrogen 


\section{Siti Hana \& Fatmawati: DETERMINATION OF PHYSICAL CROSSLLINK BETWEEN CARRAGEENAN AND GLYOXYLIC ACID USING DENSITY FUNCTIONAL THEORY CALCULATIONS}

\section{Introduction}

Kappa carrageenan (k-carrageenan) is an anionic sulphate polysaccharide with interesting pharmacology properties such as ability to inhibit hepatitis A viruses [1]. It has been used by in various studies to produce drug delivery carrier such as hydrogel [2, 3, 4], shell of microcapsules [5], and beads [6] which normally has prolonged drug release properties. This prolonged drug release properties is due to the swelling capability of k-carrageenan film such as been reported by Hezaveh and Muhammad [2] that non-crosslink k-carrageenan hydrogel can swelled up to $16 \%$ after soaked for 35 hours in $\mathrm{pH} 7$ solution. While, this study aims to produce the hard capsule using kcarrageenan which require to disintegrate in less than 15 minutes. Therefore to achieve this aim, the crosslink method has been used with physical crosslink establishment as a main target. This physical crosslink can promote rapid swelling of k-carrageenan hard capsule and ensure its ability to disintegrate as required by US pharmacopeia [7]. According to Hiemstra et al. [8], physical crosslink is a mild crosslink or interaction such as hydrogen bond interaction in which its network can be easily disrupted due to changes in the external environment. At present, the interaction studies Adam et al. [9] and Karavas et al. [10] used the computational chemistry to simulate and calculate the establishment of the interaction through calculation of radial diffusion function (RDF) and interaction energy for hydrogen bond established in the system.

In this paper, the computational study using quantum mechanics concept will be presented. The quantum mechanics calculation was carried out to determine the particular atoms involved in the physical crosslink establishment between k-carrageenan and glyoxylic acid. The electron and proton donor site can be determine and conjugate complex k-carrageenan - glyoxylic acid was set at the selected site. This then may indicate the suitability of physical cross-linked carrageen to be developed as hard capsule application. In addition the effect of physical crosslink to the k-carrageenan molecule may further investigate.

\section{Quantum Mechanics Calculation}

\section{Materials and Methods}

The density functional theory (DFT) calculations have been carried out using Gaussian 09W software at B3LYP (Becke's three-parameter functional [11] and nonlocal correlation of LYP expression [12]) level of theory; with basis set of 6-31G. The geometry optimization and frequency calculations for pure k-carrageenan, glyoxylic acid and physical crosslink conjugate complex of k-carrageenan-glyoxylic acid $(\mathrm{GaSc})$ were executed with the selected functional and correlation function. The molecule electronic surface potential (MESP) of k-carrageenan and glyoxylic acid has been generated from the geometry optimization calculation. Through this MESP, determination of the physical crosslink conjugate complex has been drawn and calculated for it optimum geometry. The crosslink point between k-carrageenan and glyoxylic acid was measured to ensure its can be categorized as hydrogen bond through calculation of interaction energy produced using Equation 1 below. While the absolute difference in muliken charges of optimized conjugate complex k-carrageenan-glyoxylic acid and k-carrageenan may indicate the probability of scission of chains. This scission effect may promote mechanical fracture (crack) of film. Figure 1 illustrates the quantum mechanics calculations steps that were carried out in this study.

Interaction energy $=$ ESCF complex $-\{$ ESCF polysaccharide + ESCF crosslinker agent $\}$ 


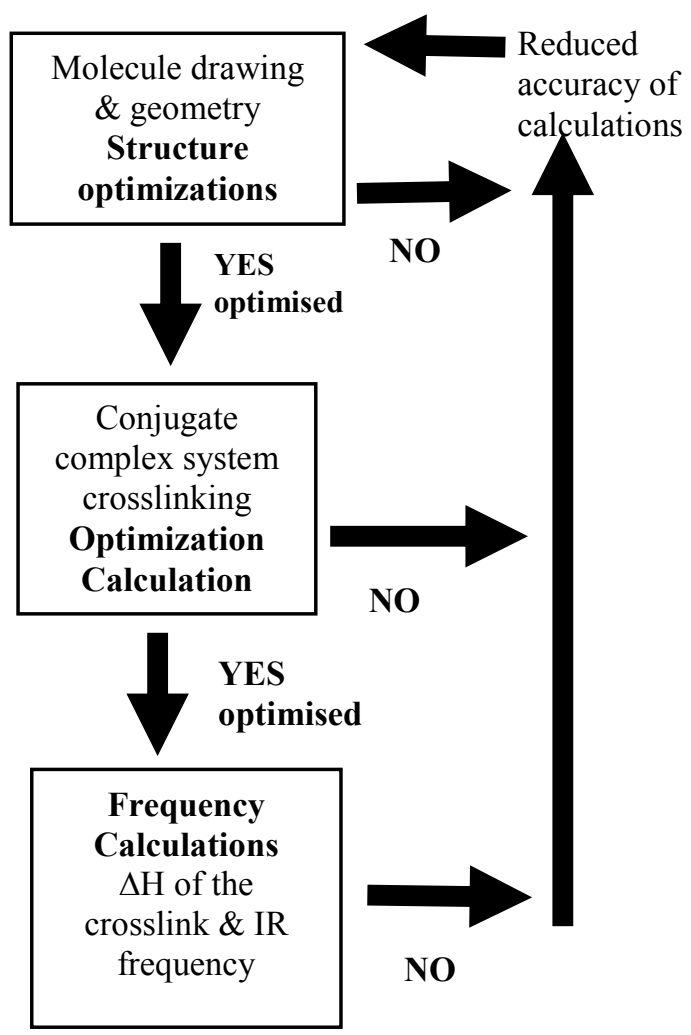

Figure 1. Summary of calculations steps using Gaussian $09 \mathrm{~W}$ in this study

\section{Results and Discussion}

The IR spectrum (Figure 2) for optimized k-carrageenan and glyoxylic acid molecules were generated from the frequency calculation. The frequency calculation was carried out after the molecules has been optimized. The positive value of vibration produced and for k-carrageenan and glyoxylic acid may indicate that the molecules geometry optimize calculation has managed to found the stationary point of the local minima on the potential energy surface. This validation technique has been suggested by Kumar et al. [13] in their quantum study of azelaic acid.

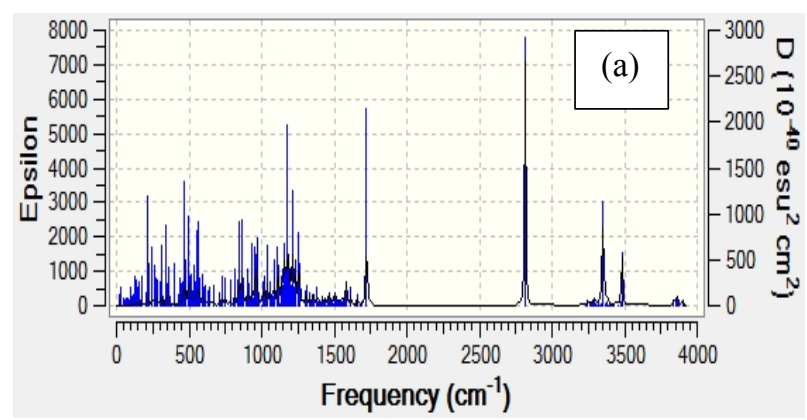




\section{Siti Hana \& Fatmawati: DETERMINATION OF PHYSICAL CROSSLLINK BETWEEN CARRAGEENAN AND GLYOXYLIC ACID USING DENSITY FUNCTIONAL THEORY CALCULATIONS}

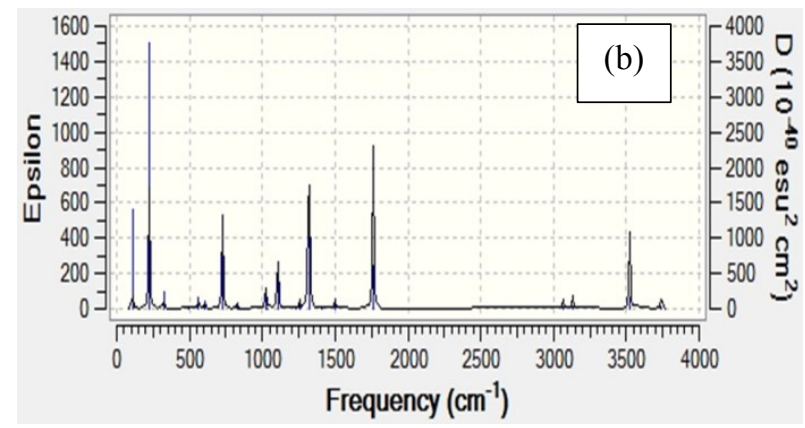

Figure 2. IR spectrum generated for optimized (a) kappa carrageenan molecule, and (b) glyoxylic acid molecule

In Figure 3 (a) and (b), the molecule electronic surface potential (MESP) for optimized k-carrageenan and glyoxylic acid illustrate the charge distributions of molecule with different values of the electrostatic surface potential at the surface. The potential increases (electron rich) in the order blue $<$ green $<$ yellow $<$ orange $<$ red. Knowledge of the charge distribution of the molecule which illustrated by electrostatic surface potential of molecule can be used to predict how molecule react to the other molecule such as suggested by Rawat and Singh [14]. Figure 4(a) shows that the negative regions in k-carrageenan are mainly localized on the oxygen and sulphur atoms which agreed with suggestion by Kumar et al. [13]. They suggested that the shapes of the electrostatic potential surface is influenced by the structure and charge density distributions in the molecule with sites close to the oxygen atom, showing region of most negative electrostatic potential. While in the glyoxylic acid, the positive regions are localized at the hydrogen atoms from hydroxyl functional group. Therefore, the physical crosslink may establish between the red region of k-carrageenan and blue region of glyoxylic acid or vice versa. The k-carrageenan will serve as an electron donor with glyoxylic acid will serve as a proton donor to establish the hydrogen bond. Tanak [15] also found negative potential site generated around Sulphur molecule using the BL3YP calculation for 4,5-bis(tertbutylsulfanyl)phthalonitrile and may serve as electron donor.

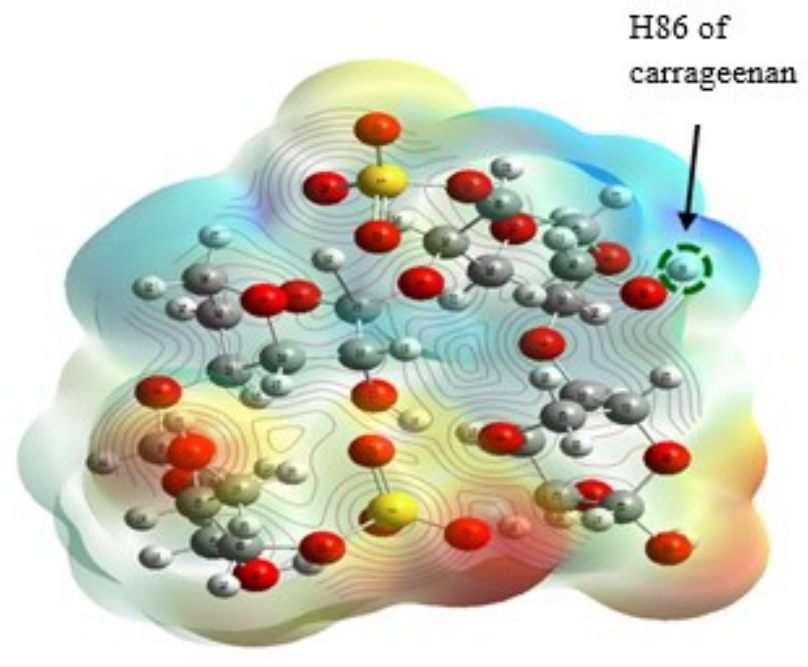

(a)
O3 of
glyoxylic acid

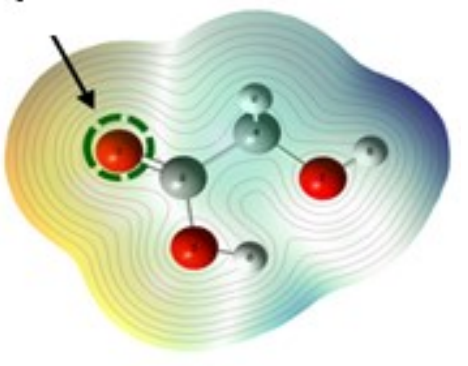

(b)

Figure 3. The molecular electrostatic potential (MESP) analysis for optimized molecule structure of (a) kcarrageenan and (b) glyoxylic acid 
In this calculation the interaction between $\mathrm{H} 86$ of k-carrageenan and $\mathrm{O} 3$ of glyoxylic acid has been set up at the length of $2.2 \AA$ at the beginning of calculation. The hydrogen bond has been established between H86 --- O3 with bond length of $1.90 \AA$ (Figure 4) after optimization step completed for conjugate complex k-carrageenan-glyoxylic acid. According to Karavas et al. [10] the hydrogen bond length established in their Gaussian calculation for kcarrageenan and fluvastatin is around $1.897 \AA$. While Adam et al. [9] calculated hydrogen bond length of $1.75 \AA$ for interaction between ethanol and patchouli in their molecular dynamic simulation. Therefore, the hydrogen bond established in this calculation is around the acceptable ranged. The hydrogen bond is the strongest intermolecular interaction $[16,17]$, which as physical crosslink, it may produce stable hard capsule shell that may promote disintegration.

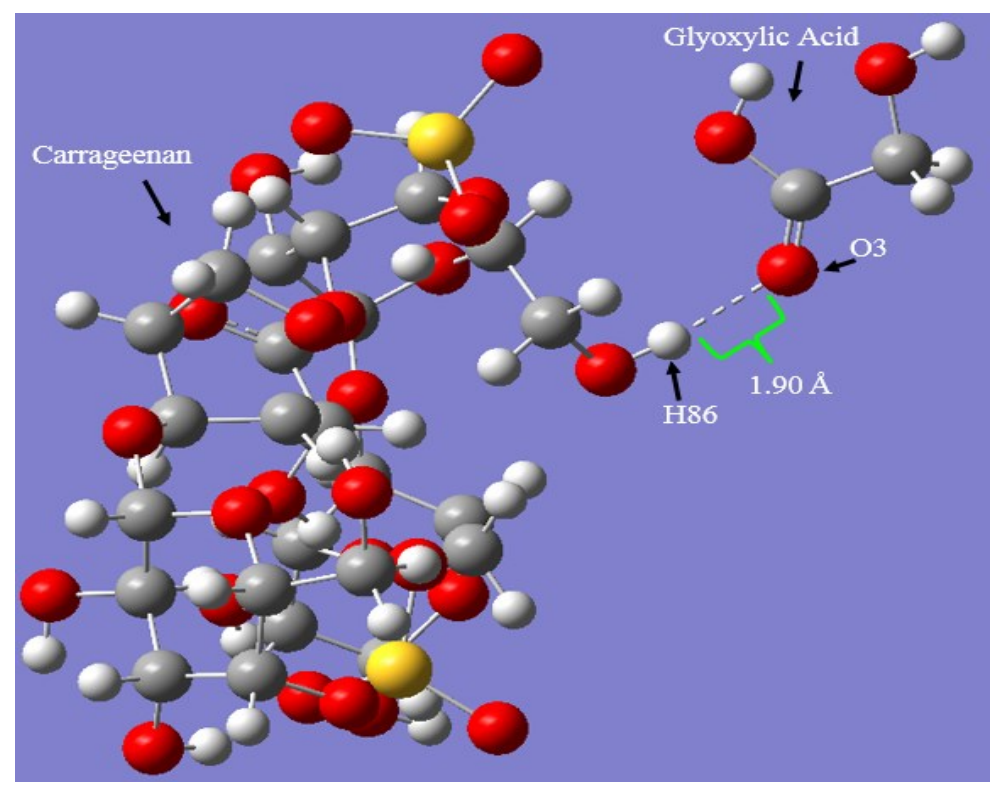

Figure 4. Hydrogen bond point between H86 --- O3 generated from the optimization calculation

The self-consistent field (SCF) energy values for optimized k-carrageenan, glyoxylic acid and conjugate complex kcarrageenan-glyoxylic acid were tabulated in Table 1 . This study calculated $-75.735 \mathrm{~kJ} \mathrm{~mol}^{-1}$ for interaction energy of hydrogen bond between k-carrageenan and glyoxylic acid using 6-31G basis set. While Karavas et al. [10] calculated $-318 \mathrm{~kJ} \mathrm{~mol}^{-1}$ for the interaction energy of hydrogen bonding between iota carrageenan and (API) fluvastatin using basis set of $6-31 \mathrm{G}^{* *}(\mathrm{~d} . \mathrm{p})$ with $* *$ as diffusion function and $(\mathrm{d}, \mathrm{p})$ as polarization function. This additional functionals may produce better result however due to computer constraint, this study only use basis set of 6-31G without additional functions. Meanwhile Reichardt and Welton [18] reported that a strong hydrogen bond interaction energy for hydrofluoric acid (HF---HF) is $-155 \mathrm{~kJ} \mathrm{~mol}^{-1}$. Thus the interaction energy calculated in this study may indicate that hydrogen bond established in the conjugate complex of k-carrageenan-glyoxylic acid weaker and can promote disintegration as well.

Table 1. SCF energy value for optimized k-carrageenan, glyoxylic acid and conjugate complex k-carrageenan-glyoxylic acid

\begin{tabular}{|c|c|}
\hline Component & $\begin{array}{l}\text { SCF energy for optimized molecule } \\
\left(\mathrm{kJ} \mathrm{mol}^{-1}\right)\end{array}$ \\
\hline k-Carrageenan & -9389839.095 \\
\hline Glyoxylic acid & -798961.796 \\
\hline k-Carrageenan - glyoxylic acid & -1018876.626 \\
\hline Interaction energy ( $\triangle \mathrm{SCF}$ energy) & -75.735 \\
\hline
\end{tabular}




\section{Siti Hana \& Fatmawati: DETERMINATION OF PHYSICAL CROSSLLINK BETWEEN CARRAGEENAN AND GLYOXYLIC ACID USING DENSITY FUNCTIONAL THEORY CALCULATIONS}

Another parameter that generated from this DFT calculations is the muliken charges of the molecule (Table 2). Sakaguchi et al. [19] reported that absolute $\Delta$ Mulliken atomic charge can be used to predict the ionic degree of the covalent bond comprising polymer main chain. They concluded that the higher absolute $\Delta$ Mulliken atomic charge, the higher ionic degree or ionic yield. While Gao et al. [20] suggest that the ionic degree indicates the hardness of covalent bond. Lower ionic degree may induce the scission of polymer chains. Therefore the absolute $\Delta$ Mulliken atomic charge of 0.492 may induce the scission that promote further disintegration of hard capsule at $\mathrm{C} 32-\mathrm{O} 5$ (Figure 5).

Table 2. Mulliken atomic charges, and absolute Mulliken atomic charges $(\triangle \mathrm{MC})$ obtained for optimized k-carrageenan and conjugate complex of k-carrageenan-glyoxylic acid.

\begin{tabular}{lcccc|c|c}
\hline Component & C32 & O5 & C34 & $\Delta$ Md C32- O5 & $\Delta$ MC & O5 - C34 \\
\hline k-Carrageenan & -1.850 & 0.180 & 0.617 & 2.030 & 0.437 \\
k-Carrageenan - glyoxylic acid & 0.054 & -0.442 & 0.691 & 0.492 & 1.133 \\
\hline
\end{tabular}

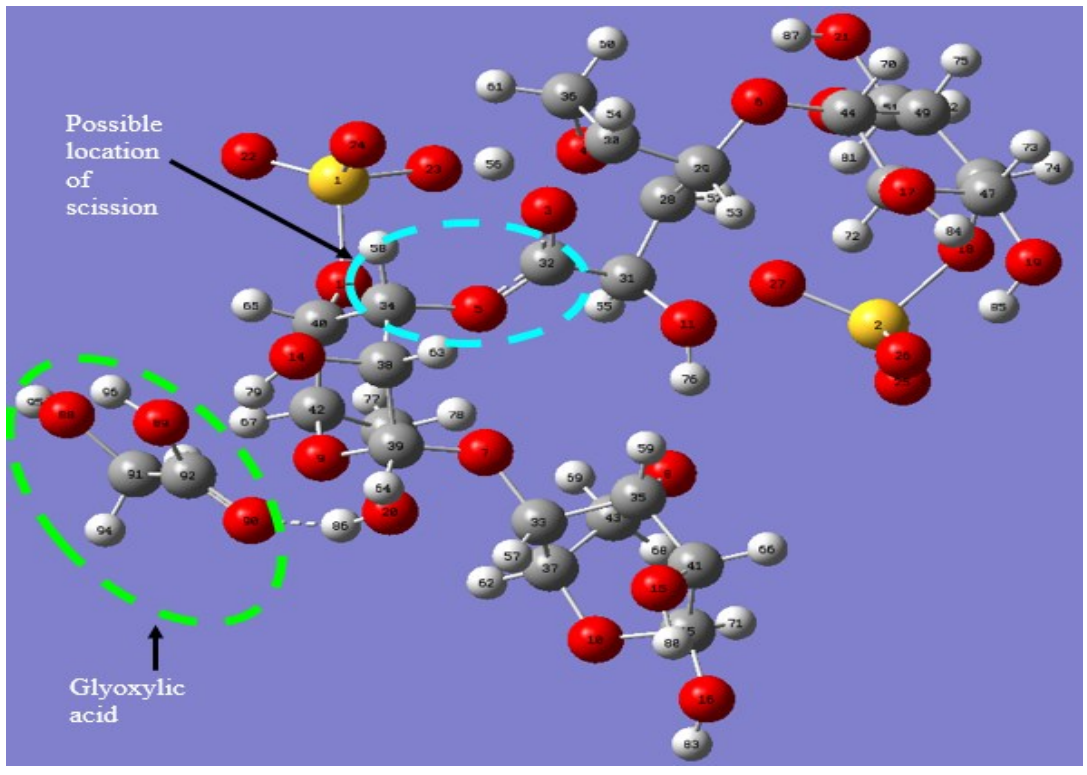

Figure 5. Probability of scission effect in conjugate complex k-carrageenan-glyoxylic chains

\section{Conclusion}

The DFT calculations to determine the physical crosslink establishment has been successfully carried out and generated positive value of vibrations indicate calculations are at the global minima. The calculated interaction energy for established hydrogen bond is $-75.735 \mathrm{~kJ} \mathrm{~mol}^{-1}$. While generated MESP for k-carrageenan and glyoxylic acid indicate that both molecules have the electron and proton donor site which can establish the hydrogen bond as physical crosslink. Furthermore the absolute $\Delta$ Mulliken atomic charge of may suggest scission effect toward main covalent bond in k-carrageenan and thus further promote disintegration of hard capsule. It is recommended that a higher accuracy calculations should be carried out through addition of diffusion and polarization functions to the basis set used in this work. 


\section{Acknowledgements}

The authors would like to acknowledge support from the Ministry of Science Technology and Innovation via EScience Grant Scheme: UMPRDU 140504 and Universiti Malaysia Pahang (FKKSA \& FIST) for the computer lab facilities. Special thanks to Assoc. Prof. Dr. Ku Halim Ku Bulat (Univerisiti Malaysia Terengganu) and Dr. Saifful Kamaluddin Muzakir (FIST, UMP) for all the quantum mechanics guidance.

\section{References}

1. Girond, S., Crance, J. M., Van Cuyck-Gandre, H., Renaudet, J. and Deloince, R. (1991). Antiviral activity of carrageenan on hepatitis A virus replication in cell culture. Research in Virology, 142: 261 - 270.

2. Hezaveh, H. and Muhamad, I. I. (2013). Modification and swelling kinetic study of kappa-carrageenan-based hydrogel for controlled release study. Journal of the Taiwan Institute of Chemical Engineers, 44(2): 182 - 191.

3. Hezaveh, H. and Muhamad, I. I. (2013b). Controlled drug release via minimization of burst release in pHresponse kappa-carrageenan/polyvinyl alcohol hydrogels. Chemical Engineering Research and Design, 91(3): $508-519$.

4. Meena, R., Prasad, K. and Siddhanta, K. (2009). Development of a stable hydrogel network based on agarkappa-carrageenan blend cross-linked with genipin. Food Hydrocolloids, 23: $497-509$.

5. Briones, A. V. and Sato, T. (2010). Encapsulation of glucose oxidase (GOD) in polyelec-trolyte complexes of chitosan-carrageenan. Reactive and Functional Polymer, 70: 19 - 27.

6. Ozsoy, Y. and Bergisadi, N. (2000). Preparation of mefenamic acid sustained release beads based on kappacarrageenan. Bollettino Chimico Farmaceutico, 139: 120 - 123.

7. USP 30 (2007). United States Pharmacopeia, chapter 701: 276 - 277.

8. Hiemstra, C., Zhong, Z., Dijikstra, P. and Feijen, J. (2009). Stereocomplexed PEG-PLA hydrogels in hydrogels: Biological properties and applications. Roland Barbucci (Editor). Springer-Verlag Italia, Milan, Italy.

9. Adam, F., A. Bakar, S. H., M. Yusoff, M. and Tajuddin, S. N. (2013). Molecular dynamic simulation of the patchouli oil extraction process. Journal of Chemical and Engineering Data, 59: 183 - 188.

10. Karavas, E., Koutris, E., Papadopoulos, A. G., Sigalas, M. P., Nanaki, S., Papageorgiou, G. Z., Achillas, D. Z. and Bikiatris, D. N. (2014). Application of density functional theory in combination with FTIR and DSC to characterise polymer drug interactions for the preparation of sustained release formulations between fluvastatin and carrageenans. International Journal of Pharmaceutics, 466: $211-222$.

11. Becke, A. D. (1993). Density-functional thermochemistry. III. The role of exact exchange. Journal of Chemical Physics, 98: 5648 - 5652.

12. Lee, C., Yang, W. and Parr, R.G. (1988). Development of the Colle-Salvetti correlation-energy formula into a functional of the electron density. Physical Review B, 37: $785-789$.

13. Kumar, A., Narayan, V., Prasad, O. and Sinha, L. (2012). Monomeric and dimeric structures, electronic properties and vibrational spectra of azelaic acid by HF and B3LYP methods. Journal of Molecular Structure, 1022: $81-88$.

14. Rawat, P. and Singh, R. N. (2015). Synthesis, conformational, spectroscopic and chemical reactivity analysis of 2-cyano-3-(1H-pyrrol-2-yl)acrylohydrazide using experimental and quantum chemical approaches. Journal of Molecular Structure, 1082: 118 - 130.

15. Tanak, H. (2015). Molecular structure, spectroscopic and DFT computational studies on 4,5-bis(tertbutylsulfanyl)phthalonitrile. Journal of Molecular Structure, 1090: 86 - 92.

16. Suchocki, J. (2000). Conceptual chemistry: Understanding our world of atoms \& molecules. $3^{\text {rd }}$ edition. Pearson Benjamin, USA.

17. Reger, D. L, Goode, S. R. and Ball, D. W. (2010) Chemistry: principles and practice. Brooks/Cole: Cengage Learning, Canada.

18. Reichardt, C. and Welton, T. (2011). Solvents and solvents effects in organic chemistry. John Wiley \& Sons Publication, USA.

19. Sakaguchi, M., Makino, M., Ohura, T. and Iwata, T. (2014). The correlation between the ionic degree of covalent bond comprising polymer main chain and the ionic yield due to mechanical fracture. Polymer, 55(8), $1917-1919$.

20. Gao, F., He, J., Wu, E., Liu, S., Yu, D., Li, D., Zhang, S. and Tian, Y. (2003). Hardness of covalent crystals. Physical Review Letters, 91: 015502. 